\title{
Drifting of Heme-Coordinating Group in Imidazolylmethylxanthones Leading to Improved Selective Inhibition of CYP11B1
}

Silvia Gobbi ${ }^{\mathrm{a}, *}$, Qingzhong $\mathrm{Hu}^{\mathrm{b}}$, Christina Zimmer ${ }^{\mathrm{c}}$, Federica Belluti ${ }^{\mathrm{a}}$, Angela Rampa ${ }^{\mathrm{a}}$, Rolf W. Hartmann $^{\mathrm{c}}$, Alessandra Bisi ${ }^{\mathrm{a}, *}$

${ }^{a}$ Department of Pharmacy and Biotechnology, Alma Mater Studiorum-University of Bologna, Via Belmeloro, 6, I-40126 Bologna, Italy

${ }^{b}$ Department of Chemistry, University of Cambridge, Lensfield Road Cambridge, CB2 1EW, UK ${ }^{c}$ Pharmaceutical and Medicinal Chemistry, Saarland University \& Helmholtz Institute for Pharmaceutical Research Saarland (HIPS), Universitätscampus E8 1, 66123 Saarbrücken, Germany

* Corresponding authors. E-mail addresses: silvia.gobbi@unibo.it (S. Gobbi), alessandra.bisi@unibo.it (A. Bisi).

${ }^{*}$ These authors contributed equally to this work. 


\title{
Keywords
}

Cytochromes, CYP11B1 (11- $\beta$-hydroxylase), CYP11B2 (aldosterone synthase), inhibitors, xanthone.

\begin{abstract}
An abnormal increase in glucocorticoid levels is responsible for pathological disorders affecting different organs and systems, and the selective inhibition of appropriate steroidogenic enzymes represents a validated strategy to restore their physiological levels. In continuing our studies on CYP11B inhibitors, in this paper a small series of 6-substituted 3-imidazolylmethylxanthones was designed and synthesized, according to the data acquired from previously reported series of derivatives and from a purposely-performed docking study. The new compounds proved to be potent inhibitors of CYP11B isoforms, being effective on CYP11B1 in the low nanomolar range and improving selectivity with respect to CYP11B2, compared to previously reported related compounds. These data further confirmed that a suitable mutual arrangement of the imidazolylmethyl pharmacophore and a properly selected substituent on the xanthone core allows a fine tuning of the activity towards the different CYPs and further corroborate the role of the xanthone scaffold as a privileged structure in this field.
\end{abstract}

\section{Introduction}

Cortisol is a glucocorticoid steroidal hormone produced in the adrenal gland and mainly released in response to stress. It is also involved in many different metabolic processes, in suppression of immune system and in neurogenesis. A dysregulation of its biosynthesis, leading to an abnormal increase of its physiologic levels, is related to life-threatening diseases, including Cushing's syndrome and chronic wound healing [1,2]. These hormone-related pathologies could be managed by reducing the excessive glucocorticoid production, acting on properly selected steroidogenic enzymes. In this 
context 11 $\beta$-hydroxylase (CYP11B1), one of the two isoforms of steroid 11-hydroxylases, catalysing the conversion of 11-deoxycortisol in cortisol in the last step of its biosynthetic pathway, can be considered a validated drug target [3]. This cytochrome is also involved in the hydroxylation of 11deoxycorticosterone in corticosterone, which is then converted in aldosterone by the other isoform of 11-hydroxylases, aldosterone synthase (CYP11B2). The overproduction of aldosterone proved to be involved in steroid-related diseases as well, such as hypertension, congestive heart failure and myocardial fibrosis [4].

These enzyme isoforms are mainly expressed in the adrenal cortex, CYP11B1 in the zona fasciculata and CYP11B2 in the zona glomerulosa, and share a degree of sequence homology up to $93 \%$, making the design of specific and selective inhibitors particularly challenging. In recent years, highly selective CYP11B2 inhibitors have been reported [5-8], characterized by a significant structural scaffold variance, still bearing the key features for an efficient cytochrome inhibition, such as nitrogen-containing heterocyclic functions (pyridine or imidazole), able to interact with the hemeiron of the active site.

Despite some exciting progresses in the development of selective compounds have been recently reported [9-11], no specific CYP11B1 inhibitor has been approved to treat hypercortisolism. Metyrapone (Figure 1) is the only CYP11B inhibitor used in some countries for adrenal insufficiency diagnosis and occasionally in Cushing's syndrome, but its poor selectivity accounts for the onset of several side effects. It is also worth noting that the antifungal drug ketoconazole and the anesthetic etomidate (Figure 1) could be used as multiple enzyme inhibitors in the management of Cushing syndrome, although the emergence of toxicity issues should be carefully monitored [12]. Taking these drawbacks into account, several studies are in progress in order to obtain more active and selective potential drugs. In particular, starting from the structure of etomidate, a series of more rigid pyrrolo quinolinone derivatives (Figure 1) were designed as CYP11B1 inhibitors and further optimized, leading to more selective compounds with respect to CYP11B2 [13]. Moreover, a series of pyridylmethyl 
isoxazole derivatives (Figure 1) endowed with nanomolar inhibition potency on CYP11B1 and a better selectivity factor over aldosterone synthase with respect to metyrapone were very recently described [14].<smiles>CC(C)(C(=O)c1cccnc1)c1cccnc1</smiles>

Metyrapone<smiles>CC(=O)N1CCN(c2ccc(OC[C@H]3CO[C@@](Cn4ccnc4)(c4ccc(Cl)cc4Cl)O3)cc2)CC1</smiles>

Ketoconazole<smiles>CCOC(=O)c1cncn1C(C)c1ccccc1</smiles>

Etomidate<smiles>O=C1CCc2cc(C(C3CC3)n3ccnc3)cc3c2N1CC3</smiles><smiles>COc1cncc(Cc2cc(-c3ccccc3)no2)c1</smiles>

Figure 1. Representative CYP11B1 inhibitors.

In recent papers we reported the design and synthesis of two different series of 1imidazolylmethylxanthones (1-ImiXs), carrying different substituents either in position 4 [15] or in position 6 [16] of the central core, as potent inhibitors of CYP11B enzymes (Figure 2). These compounds were designed on the basis of the hits retrieved from a virtual screening of our aromatase (CYP19) inhibitors library of compounds on CYP11B2, used as starting point for subsequent optimisation, taking into account the different features emerged from the pharmacophore search. When comparing the results of the biological evaluation of these two sets of molecules, it could be seen that the shift of substituents from position 4 to position 6 led to a general decrease in the inhibitory potency toward both enzymes, although for a couple of compounds (fluorine and nitro 
derivatives) low-nanomolar range activities were observed. This could be the result of different effects, i.e. a less appropriate fitting of 6-substituted compounds in the binding site and/or the modification of the relative location of the substituents and the imidazolylmethyl side chain, the crucial moiety for the primary interaction of the molecule with the heme iron of the enzyme, leading to its positioning into the binding site.

On the other hand, from the initial virtual screening, the compound carrying a 3-imidazolylmethyl moiety and no further substitution on the central core [17] emerged among unsubstituted ImiXs as the most promising potential selective inhibitor of CYP11B1 (see Table 1).

Taken together, all these data proved the role of the xanthone core as a valuable scaffold for the development of different cytochromes inhibitors. This planar oxygenated heterocycle could be considered as a "privileged structure" for the inhibition of CYP11B1 and CYP11B2 as its large conjugated $\pi$ system could conveniently form $\pi-\pi$ interactions with the many aromatic amino acid residues in the active sites. Since the competitive inhibition is a consequence of the coordination of the $s p^{2}$ hybridized imidazole $\mathrm{N}$ to the heme iron, which normally shows a perpendicular setting, and thus acts as an anchor to binding [18], alteration of the substitution pattern could change the orientation of the whole molecule and therefore lead to different inhibitory activity against these two homologue enzymes.

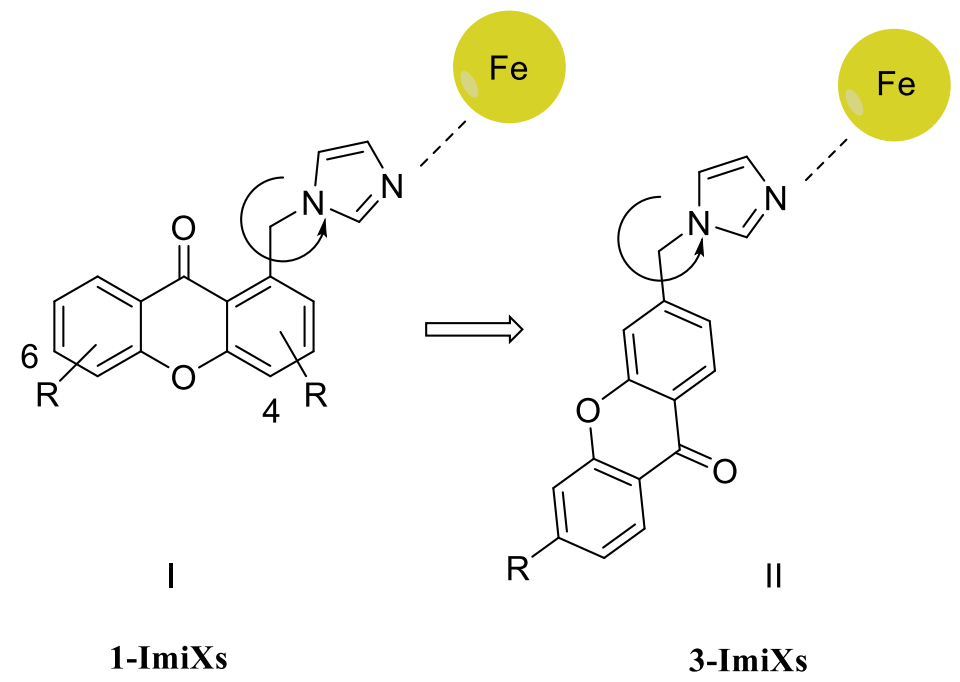


Figure 2. Design of the studied compounds.

Therefore, 1-ImiX (compound I, Figure 2) and 3-ImiX (II, Figure 2) were docked in the CYP11B1 homology model [19] and CYP11B2 crystal (PDB ID: 4dvq) [20] to virtually evaluate the possibility of achieving selectivity (Figures 3 and 4). Unsurprisingly, both compounds perpendicularly coordinate to the heme iron with their $s p^{2}$ hybridized imidazole $\mathrm{N}$ and the xanthone core is positioned nearly parallel to the heme plane (Figures 3A and 3B). This core also stretches away from the I-helix, points to the $\beta-\beta^{\prime}$ loop and parallels to the $\beta 2$ sheet (Figure $3 \mathrm{~A}$ ), similar to some previously identified CYP11B inhibitors [21,22]. In CYP11B2 crystal, the xanthone core leans on the $\beta 2$ sheet; while it swings to the $\beta^{\prime}-\mathrm{C}$ loop in the CYP11B1 homology model due to the subsidence of Phe130 (Figures 3C and 3D). In the CYP11B1 model, both compounds adopt very similar binding poses in contrast to the perpendicular intersection observed in the CYP11B2 crystal (Figure 3D). Accordingly, both 1and 3-ImiXs exhibited similarly high fitness scores to CYP11B1 (45.15 for 1-ImiX and 46.04 for 3ImiX); where a significant difference was observed regarding CYP11B2 (42.13 for 1-ImiX and 33.06 for 3-ImiX). This finding reflects different binding poses of these compounds, although both form the same $\pi-\pi$ interactions with Phe130, Phe381 and Phe487 in CYP11B2 (Figures 4A and 4C). Compared to their binding in CYP11B2, more $\pi-\pi$ interactions with Trp116 (1- and 3-ImiX) and Phe231 (1-ImiX) were observed in CYP11B1 (Figures 4B and 4D). 3-ImiX also forms hydrogen bond with Arg110 through its ether O (Figure 4D). As the docking study successfully echoed the potent but non-selective inhibition of CYP11B1 (fitness score of 45.15 and $\mathrm{IC}_{50}$ of $99.1 \mathrm{nM}$ ) and CYP11B2 (fitness score of 42.13 and $\mathrm{IC}_{50}$ of $114.3 \mathrm{nM}$ ) caused by 1-ImiX (Table 1), the difference in fitness scores (46.04 for CYP11B1 and 33.06 for CYP11B2) seen for 3-ImiX may indicate strong inhibition of CYP11B1 and selectivity over CYP11B2.

To validate this virtual evaluation 3-ImiX, together with 2- and 4-ImiX [23], were then resynthesized and tested (Table 1). As predicted, 3-ImiX showed potent inhibition of CYP11B1 $\left(\mathrm{IC}_{50}=70.8 \mathrm{nM}\right)$ 
and selectivity of 4.9. In contrast to the weak inhibition showed by 2-ImiX, 4-ImiX analogue turned out to be the most potent one in this comparison $\left(\mathrm{IC}_{50}\right.$ of 15.1 and $43.7 \mathrm{nM}$ for CYP11B1 and CYP11B2, respectively), although being less selective ( $\mathrm{SF}=2.9)$ compared to 3-ImiX. Encouraged by these results, a small library of appropriately substituted 3-ImiXs were synthesized and tested against CYP11B1 and CYP11B2 (Table 2). In particular, the scaffold was decorated with an array of substituents endowed with different steric and electronic properties, selected among the most promising ones emerged from previously reported series.

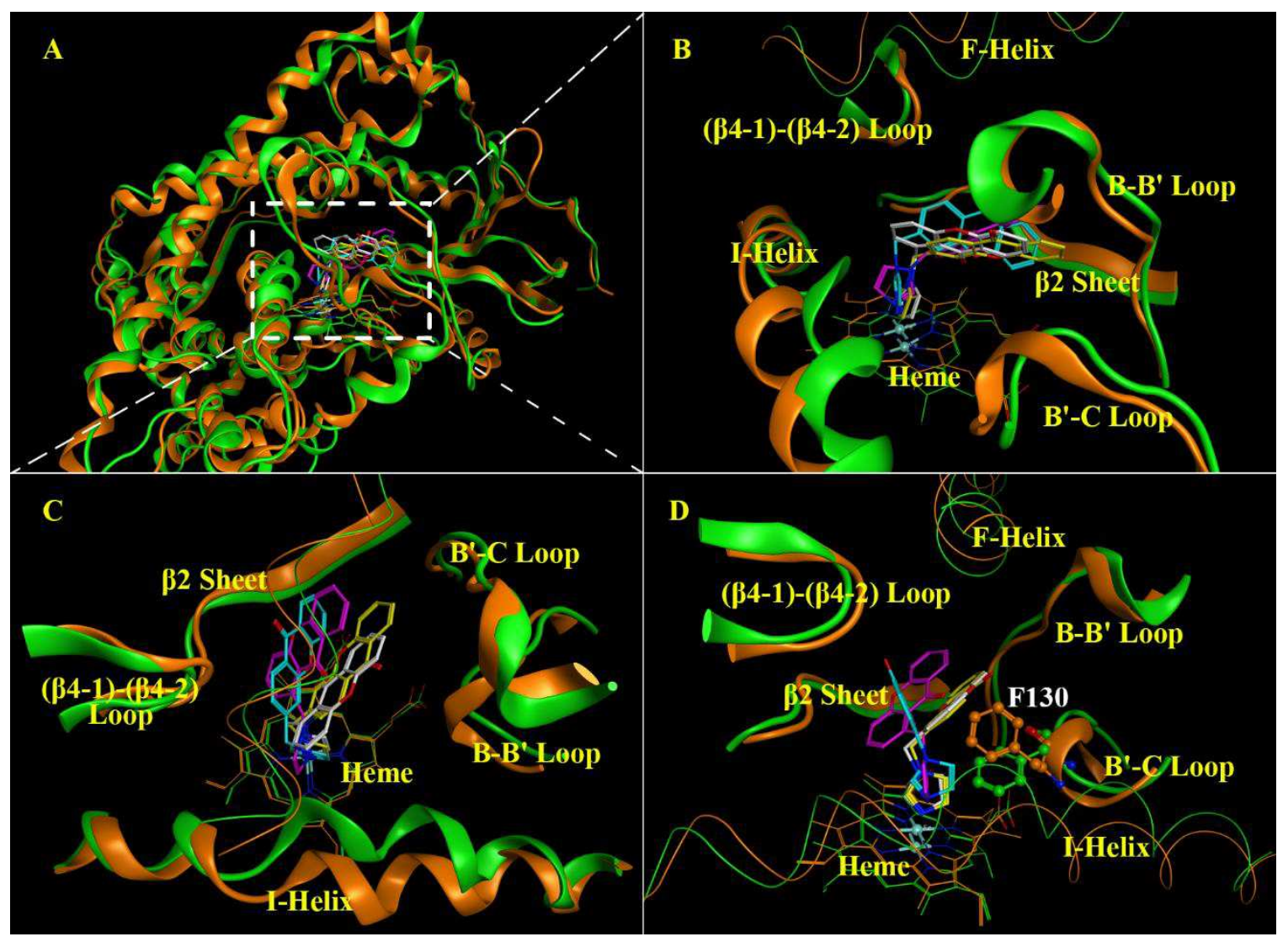

Figure 3. The binding of compounds 1-ImiX (white in CYP11B1 and magenta in CYP11B2) and 3ImiX (yellow in CYP11B1 and cyan in CYP11B2) in CYP11B1 homology model (light green) and CYP11B2 crystal (PDB ID: 4DVQ, orange). 


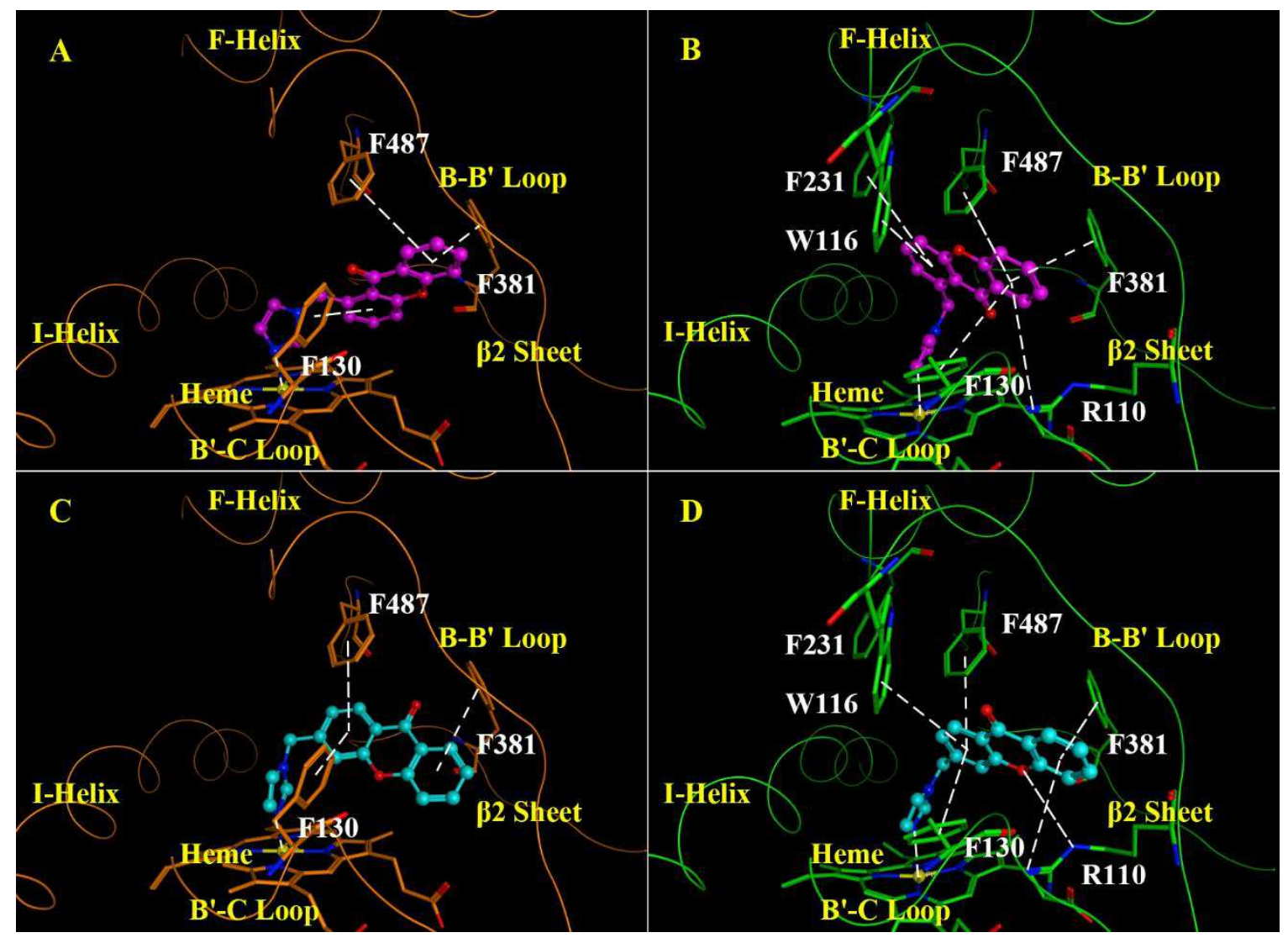

Figure 4. Interactions between the docked compounds and active sites of CYP11B1 homology model (light green, in figures 4B and 4D) and CYP11B2 crystal (PDB ID: 4DVQ, orange, in figures 4A and 4C). Compound I (1-ImiX) was illustrated in magenta (in figures 4A and 4B) and II (3-ImiX) in cyan (in figures 4C and 4D).

Table 1. Inhibition of CYP11B1 and CYP11B2 for unsubstituted ImiXs.

\begin{tabular}{|c|c|c|c|c|}
\hline \multirow[b]{2}{*}{ Compound } & \multicolumn{4}{|c|}{$\mathrm{IC}_{50}(\mathrm{nM})$} \\
\hline & code & CYP11B1 $^{a}$ & $\mathrm{CYP} 11 \mathrm{B2} 2^{b}$ & $\mathbf{S F}^{c}$ \\
\hline & 1-ImiX & $99.1 \pm 11.2$ & $114.3 \pm 15.3$ & 1.2 \\
\hline & 2-ImiX & $463.0 \pm 20.8$ & $1140.4 \pm 98.0$ & 2.5 \\
\hline
\end{tabular}




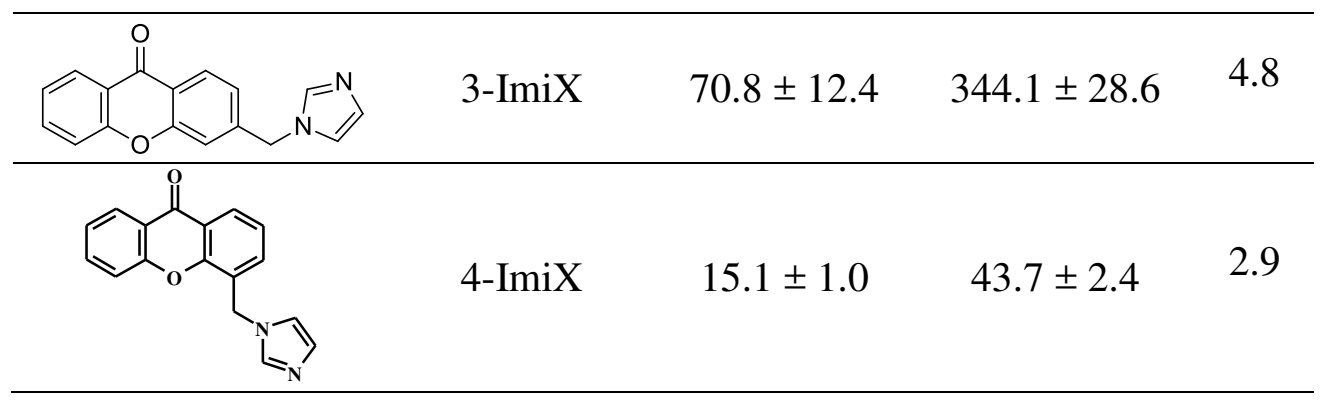

${ }^{\bar{a}}$ Hamster fibroblasts expressing human CYP11B1; substrate: deoxycorticosterone $100 \mathrm{nM} .{ }^{b} \mathrm{Hamster}$ fibroblasts expressing human CYP11B2; substrate: deoxycorticosterone $100 \mathrm{nM}$. ${ }^{c}$ Selectivity Factor $=\mathrm{IC}_{50} \mathrm{CYP} 11 \mathrm{~B} 2 / \mathrm{IC}_{50} \mathrm{CYP} 11 \mathrm{~B} 1$.

\section{Results and discussion}

\subsection{Chemistry}

For the synthesis of the studied 6-substituted 3-ImiX 1a-i, the corresponding 3-methylxanthones 2ai were brominated with $\mathrm{N}$-bromosuccinimide (NBS) and subsequently reacted with imidazole (Scheme 1). Compounds 2a [16], 2b,c,f,g [24] and 2e [25] were previously described and were synthesized according to literature procedures. 3-bromo-6-methylxanthen-9-one (2d) was obtained by reduction of the nitro group of $\mathbf{2 a}$, followed by diazotization and treatment with $\mathrm{HBr}$ and $\mathrm{CuBr}$ (Scheme 2), while 3-(cyclopropylmethoxy)-6-methylxanthen-9-one (2h) and 3-methyl-6phenoxyxanthen-9-one (2i) were prepared by treating the 3-chloro derivative 2c with cyclopropylmethanol/phenol sodium salt in dioxane or dimethylformamide (DMF) (Scheme 2).<smiles>[R]c1ccc2c(=O)c3ccc(C)cc3oc2c1</smiles>

2a-i<smiles>[R]c1ccc2c(=O)c3ccc(Cn4ccnc4)cc3oc2c1</smiles>

$1 \mathbf{a}-\mathbf{i}$

Scheme 1. Synthesis of studied compounds 1a-i. Reagents and conditions: i) NBS, BPO, $\mathrm{CCl}_{4}$, reflux, $6 \mathrm{~h}$; ii) imidazole, $\mathrm{CH}_{3} \mathrm{CN}, \mathrm{N}_{2}$, reflux, $6 \mathrm{~h}$. 
<smiles>Cc1ccc2c(=O)c3ccc([N+](=O)[O-])cc3oc2c1</smiles>

2a<smiles>CC#CC</smiles>

2c<smiles></smiles>

2d

Scheme 2. Synthesis of intermediates 2d,h,i. Reagents and conditions: i) $\mathrm{SnCl}_{2}, \mathrm{EtOH}$, reflux, 2 h; ii) $\mathrm{NaNO}_{2}, \mathrm{HBr}, \mathrm{CuBr}, 16 \mathrm{~h}$; iii) $\mathrm{ROH}, \mathrm{Na}$, dioxane or DMF, reflux, 6-62 h.

\subsection{Biological evaluation}

The results of the biological evaluation of these new xanthone derivatives on CYP11B1 and CYP11B2, depicted in Table 1, show that very potent inhibitors of the two enzymes were obtained. Taking into account the activity of the unsubstituted 3-ImiX, a slight decrease in potency towards CYP11B2 could be seen with respect to the previously reported unsubstituted 1-ImiX [15] (344.1 nM vs $114.3 \mathrm{nM}$, respectively), making the new compound more selective for CYP11B1, for which the same potency was observed (70.8 nM vs $99.1 \mathrm{nM}$, respectively). Moreover, for 3-ImiX, the introduction of substituents in position 6 always led to an increase in the inhibitory potency towards both enzymes, whereas the same pattern of substitution on 1-ImiX proved in most cases unfavourable for activity.

Table 2. Structures of the studied compounds and their inhibition of CYP11B1 and CYP11B2. 
<smiles>[R]c1ccc2c(=O)c3ccc(Cn4ccnc4)cc3oc2c1</smiles>

\begin{tabular}{|c|c|c|c|c|}
\hline \multirow{2}{*}{ Compound } & \multicolumn{4}{|c|}{$\mathrm{IC}_{50}(\mathrm{nM})$} \\
\hline & $\mathbf{R}$ & CYP11B1 $^{a}$ & $\mathrm{CYP11B2}^{b}$ & $\mathbf{S F}^{c}$ \\
\hline $1 \mathbf{a}$ & $\mathrm{NO}_{2}$ & $19.2 \pm 1.8$ & $135.1 \pm 9.5$ & 7.0 \\
\hline $1 b$ & $\mathrm{~F}$ & $12.3 \pm 1.7$ & $82.0 \pm 4.8$ & 6.7 \\
\hline 1c & $\mathrm{Cl}$ & $6.6 \pm 1.1$ & $95.3 \pm 6.6$ & 14.4 \\
\hline 1d & $\mathrm{Br}$ & $11.4 \pm 1.2$ & $44.4 \pm 4.2$ & 3.9 \\
\hline $1 \mathrm{e}$ & & $15.4 \pm 1.4$ & $45.4 \pm 1.6$ & 2.9 \\
\hline 1f & & $4.1 \pm 0.7$ & $16.6 \pm 2.5$ & 4.0 \\
\hline $1 g$ & & $5.8 \pm 0.7$ & $20.3 \pm 1.7$ & 3.5 \\
\hline $1 \mathrm{~h}$ & $\triangle \mathrm{C}$ & $4.7 \pm 0.6$ & $22.3 \pm 2.1$ & 4.7 \\
\hline $1 \mathbf{i}$ & & $6.5 \pm 0.6$ & $26.2 \pm 3.7$ & 4.0 \\
\hline
\end{tabular}

${ }^{a}$ Hamster fibroblasts expressing human CYP11B1; substrate: deoxycorticosterone $100 \mathrm{nM} .{ }^{b}$ Hamster fibroblasts expressing human CYP11B2; substrate: deoxycorticosterone $100 \mathrm{nM}$. ${ }^{c}$ Selectivity Factor $=\mathrm{IC}_{50} \mathrm{CYP} 11 \mathrm{~B} 2 / \mathrm{IC}_{50} \mathrm{CYP} 11 \mathrm{~B} 1$.

When comparing the new derivatives with the corresponding 6-substituted 1-ImiXs, it emerges that shifting the imidazolylmethyl moiety from position 1 to position 3 on the scaffold led to a remarkable 
general increase in potency on both CYP11B1 and CYP11B2 for the new compounds. In particular, activities in the low-nanomolar range were recorded for the inhibition of CYP11B1. The most striking differences with respect to the previous 1-methylimidazolyl series were seen with the phenoxy derivative 1i, for which a 260-fold increase in activity on CYP11B1 could be seen, the isopropyl 1f (85-fold increase) and the chlorine derivative 1c (80-fold increase).

Among the different decorating moieties introduced in position 6 of the xanthone core, alkoxy groups, independent of their size, and a bromine atom seemed to be preferred for activity on CYP11B2, whereas there seemed to be no significant influence of size or electronic properties of substituents on inhibition of CYP11B1, since low-nanomolar range potency was always maintained. Indeed, chlorine atom, isopropoxy and phenoxy groups all gave comparable results (ranging from 4.1 to $6.6 \mathrm{nM}$ ). Nevertheless, for both isoforms the presence of a functional group in position 6 seems to be essential to achieve high potency, showing the bare derivative 3-ImiX a significant drop in activity (up to 15fold on CYP11B1). This finding, not in line with results obtained with 1-ImiXs, could be due to the difference in the position of the key interacting imidazole on the scaffold, leading to a more appropriate arrangement of the whole molecule in the binding site.

The modification performed in this new series led to compounds endowed with higher potency on CYP11B1 with respect to CYP11B2. When these results are compared with the previous series, an inversion of selectivity can be observed, since 1-ImiXs showed higher activity on CYP11B2, even if selectivity was unsatisfactory. The shift of the crucial heme-coordinating group to position 3 seemed indeed to significantly drive selectivity towards CYP11B1, playing the substituents introduced on the scaffold only a minor role: with respect to the unsubstituted compound, the nitro (1a) and the fluorine (1b) derivatives were somewhat more selective, whereas the chlorine derivative 1c, showing a SF of 14.4, proved to be the most promising compound of the series.

\section{Conclusions}


To get new insight in the studies on the inhibition of steroidogenic CYPs with xanthone-based structures, a series of 6-substituted 3-ImiXs was designed and synthesized on the basis of the docking of different unsubstituted ImiXs on CYP11B1 and CYP11B2 and of previously reported series of related compounds.

The introduction of the methylimidazolyl moiety in position 3 led to a different positioning of the planar xanthone core, allowing a better fit of the molecule into the active site of both enzymes. Moving the imidazolylmethyl moiety from position 1 to position 3 led to a remarkable shift in activity towards CYP11B1, leading to compounds endowed of low-nanomolar potency for the inhibition of this enzyme. Overall in this new series, more than in previously reported ones, it seems that the nature of substituents does not play a significant role for activity on this isoform. Indeed, no discrimination between substituents on the basis of size and electronic properties could be observed for the interaction with the enzyme, even if the presence of a functional group in position 6 seems indeed to be essential to achieve high potency.

To complete the picture, as regards selectivity, this pattern of substitution seemed in some cases to better discriminate between the two isoforms leading to compounds from 7- to 14-fold selective towards CYP11B1, even if this issue remains to be fully addressed. Among the new derivatives 1c, carrying a chlorine atom in position 6 , proved to be one of the most potent and the most selective compound on CYP11B1.

In conclusion, these results once more confirmed that the appropriate mutual positioning of the imidazolylmethyl essential pharmacophore and a suitable substituent on the xanthone core allow a fine tuning of the activity towards the different CYPs, highlighting the potential of this oxygenated heterocycle as a privileged structure in medicinal chemistry.

\section{Experimental section}




\subsection{General Methods.}

Starting materials, unless otherwise specified, were used as high-grade commercial products. Solvents were of analytical grade. Melting points were determined in open glass capillaries using a Büchi apparatus and are uncorrected. ${ }^{1} \mathrm{H}$ and ${ }^{13} \mathrm{C}$ NMR spectra were recorded on a Varian Gemini 400 spectrometer in $\mathrm{CDCl}_{3}$ solutions unless otherwise indicated, with $\mathrm{Me}_{4} \mathrm{Si}$ as the internal standard. Standard abbreviations indicating spin multiplicities are given as follows: $\mathrm{s}$ (singlet), $\mathrm{d}$ (doublet), $\mathrm{t}$ (triplet), br (broad), q (quartet) or m (multiplet). Direct infusion ES-MS spectra were recorded on a Waters Micromass ZQ 4000 apparatus. Silica gel (Merck, 230-400 mesh) was used for purification with flash chromatography. Reactions were followed by thin layer chromatography (TLC) on precoated silica gel plates (Merck Silica Gel 60 F254) and then visualized with a UV lamp. Chemical purities of the tested compounds were determined by elemental analysis $(\mathrm{C}, \mathrm{H}, \mathrm{N})$ and confirmed $\geq$ 95\% purity. Compounds were named relying on the naming algorithm developed by CambridgeSoft Corporation and used in ChemDraw Professional 15.0.

\subsection{Synthesis}

4.2.1. 3-amino-6-metil-9H-xanten-9-one (3). A mixture of 2a [16,26] $(0.50 \mathrm{~g}, 1.96 \mathrm{mmol})$ and $\mathrm{SnCl}_{2}$ $(2.23 \mathrm{~g}, 11.76 \mathrm{mmol})$ in $\mathrm{EtOH}$ was refluxed for $2 \mathrm{~h}$ and the solvent was then removed under reduced pressure. The residue was resuspended in ethyl acetate, washed with water and evaporated to dryness to obtain 3 (0.43 g, $97 \%$ ), mp 170-171 ${ }^{\circ} \mathrm{C} .{ }^{1} \mathrm{H}$ NMR: $\delta 2.49$ (s, 3H, $\left.\mathrm{CH}_{3}\right), 4.37$ (br, 2H, $\left.\mathrm{NH}_{2}\right), 6.58$ (d, $J=2.0 \mathrm{~Hz}, 1 \mathrm{H}$, arom), $6.65(\mathrm{dd}, J=8.8$ and $2.4 \mathrm{~Hz}, 1 \mathrm{H}$, arom), $7.16(\mathrm{~d}, J=8.0 \mathrm{~Hz}, 1 \mathrm{H}$, arom), 7.22 (s, 1H, arom), 8.13 (d, $J=8,8 \mathrm{~Hz}, 1 \mathrm{H}$, arom), 8.19 (d, $J=8.0 \mathrm{~Hz}, 1 \mathrm{H}$, arom).

4.2.2. 3-bromo-6-methyl-9H-xanthen-9-one (2d). A solution of $\mathbf{3}(0.43 \mathrm{~g}, 1.91 \mathrm{mmol})$ in $\mathrm{HBr}(9.40$ $\mathrm{mL})$ was treated with $\mathrm{NaNO}_{2}(0.13 \mathrm{~g}, 1.91 \mathrm{mmol})$, stirred for $20 \mathrm{~min}$ and then dropped in a boiling solution of $\mathrm{CuBr}(0.13 \mathrm{~g}, 0.91 \mathrm{mmol})$ in $\mathrm{H}_{2} \mathrm{O}(1 \mathrm{~mL})$. The mixture was stirred at $\mathrm{rt}$ overnight and poured onto ice. The precipitate was collected, dried and purified by flash chromatography (eluent 
petroleum ether/ethyl acetate 4.5:0.5), to obtain 7a (0.19 g, $27 \%)$, mp 146-148 ${ }^{\circ} \mathrm{C} .{ }^{1} \mathrm{H}$ NMR: $\delta 2.53$ (s, 3H, $\left.\mathrm{CH}_{3}\right), 7.23$ (d, $J=8.4 \mathrm{~Hz}, 1 \mathrm{H}$, arom), 7.29 (s, $1 \mathrm{H}$, arom), 7.50 (dd, $J=8.4$ and $2.0 \mathrm{~Hz}, 1 \mathrm{H}$, arom), 7.69 (d, $J=2.0 \mathrm{~Hz}, 1 \mathrm{H}$, arom), 8.19-8.22 (m, 2H, arom).

4.2.3. 3-(cyclopropylmethoxy)-6-methyl-9H-xanthen-9-one (2h). $\mathrm{Na}(0.50 \mathrm{~g}, 21.75 \mathrm{mmol})$ was dissolved with heating in a mixture of cyclopropanemethanol $(2 \mathrm{~mL})$ and dioxane $(5 \mathrm{~mL})$, then a solution of $2 \mathbf{c}$ [24] $(0.50 \mathrm{~g}, 2.05 \mathrm{mmoli})$ in dioxane $(10 \mathrm{~mL})$ was added. The mixture was refluxed for $62 \mathrm{~h}$, poured into ice and the crude was filtered and purified by flash chromatography (eluent petroleum ether/ethyl acetate 9.5:0.5) to obtain $2 \mathbf{h}(0.08 \mathrm{~g}, 15 \%)$, mp 126-127 ${ }^{\circ} \mathrm{C} .{ }^{1} \mathrm{H}$ NMR: $\delta 0.41$ $0.43\left(\mathrm{~m}, 2 \mathrm{H}, \mathrm{CH}_{2}\right), 0.70-0.72\left(\mathrm{~m}, 2 \mathrm{H}, \mathrm{CH}_{2}\right), 1.31-1.40(\mathrm{~m}, 1 \mathrm{H}, \mathrm{CH}), 2.51\left(\mathrm{~s}, 3 \mathrm{H}, \mathrm{CH}_{3}\right), 3.94(\mathrm{~d}, J=$ $\left.6.8,2 \mathrm{H}, \mathrm{CH}_{2} \mathrm{O}\right), 6.86(\mathrm{~d}, J=2.0 \mathrm{~Hz}, 1 \mathrm{H}, \operatorname{arom}), 6.96(\mathrm{dd}, J=8.8$ and $2.4 \mathrm{~Hz}, 1 \mathrm{H}$, arom $), 7.19(\mathrm{~d}, J=$ $8.0 \mathrm{~Hz}, 1 \mathrm{H}, \operatorname{arom}), 7.26$ (s, 1H, arom), $8.22(\mathrm{~d}, J=8.0 \mathrm{~Hz}, 1 \mathrm{H}$, arom), 8.25 (d, $J=8.4 \mathrm{~Hz}, 1 \mathrm{H}$, arom).

4.2.4. 3-methyl-6-phenoxy-9H-xanthen-9-one (2i). Phenol (0.19 g, $2.02 \mathrm{mmol})$ was added to a solution of $\mathrm{Na}(0.05 \mathrm{~g}, 2.17 \mathrm{mmol})$ in ethanol $(5 \mathrm{~mL})$ and the reaction mixture was stirred at $\mathrm{rt}$ for 15 min and evaporated to dryness. A solution of $2 \mathrm{c}$ [24] $(0.50 \mathrm{~g}, 2.05 \mathrm{mmol})$ in dimethylformamide (DMF, $30 \mathrm{~mL}$ ) was then slowly added and the reaction mixture was refluxed $6 \mathrm{~h}$, poured into ice and the crude was filtered and purified by flash chromatography (eluent toluene/petroleum ether 3.5:1.5) to obtain $2 \mathbf{i}(0.22 \mathrm{~g}, 37 \%)$, mp $82-83{ }^{\circ} \mathrm{C} .{ }^{1} \mathrm{H}$ NMR (acetone- $\left.d_{6}\right): \delta 2.51\left(\mathrm{~s}, 3 \mathrm{H}, \mathrm{CH}_{3}\right), 6.92(\mathrm{~d}, J=2.4$ $\mathrm{Hz}, 1 \mathrm{H}$, arom), 7.08 (dd, $J=8.4$ and $2.0 \mathrm{~Hz}, 1 \mathrm{H}$, arom), 7.22-7.24 (m, 2H, arom), 7.28-7.36 (m, 3H, arom), 7.51-7.55 (m, 2H, arom), $8.13(\mathrm{~d}, J=8.4 \mathrm{~Hz}, 1 \mathrm{H}$, arom), $8.23(\mathrm{~d}, J=8.8 \mathrm{~Hz}, 1 \mathrm{H}$, arom).

\subsection{General procedure for the synthesis of $1 \mathrm{a}-\mathrm{i}$}

A mixture of the selected 3-methylxanthenone (2a-i, 1 eq), $N$-bromosuccinimide (NBS, 1 eq) and a catalytic amount of benzoyl peroxide (BPO) in $\mathrm{CCl}_{4}$ was refluxed for $6 \mathrm{~h}$. The mixture was hot filtered and evaporated to dryness. The residue, without further purification, was dissolved in acetonitrile, imidazole ( $3 \mathrm{eq}$ ) was added and the mixture was refluxed for $6 \mathrm{~h}$ under nitrogen, evaporated to dryness and the residue was purified by flash chromatography. 
4.3.1. 3-(1H-imidazol-1-yl)methyl-6-nitro-9H-xanthen-9-one (1a). Starting from 2a [16,26] $(0.35$ $\mathrm{g}, 1.4 \mathrm{mmol}), 0.33 \mathrm{~g}$ of crude bromomethyl derivative were obtained, that were reacted with imidazole $(0.27 \mathrm{~g}, 4.2 \mathrm{mmol})$ and purified by flash chromatography (eluent: ethyl acetate) to yield $\mathbf{1 a}(0.24 \mathrm{~g}$, $53 \%$ ), mp 200-202 ${ }^{\circ} \mathrm{C} .{ }^{1} \mathrm{H}$ NMR: $\delta 5.28$ (s, 2H, $\mathrm{CH}_{2}$ ), 6.97 (s, 1H, arom), 7.22-7.25 (m, 2H, arom), $7.56(\mathrm{~s}, 2 \mathrm{H}$, arom), $8.15(\mathrm{dd}, J=8.4$ and $2.0 \mathrm{~Hz}, 1 \mathrm{H}$, arom), $8.21(\mathrm{~d}, J=8.4 \mathrm{~Hz}, 1 \mathrm{H}$, arom), $8.27(\mathrm{~s}$, $1 \mathrm{H}$, arom), $8.42\left(\mathrm{~d}, J=8.4 \mathrm{~Hz}, 1 \mathrm{H}\right.$, arom). ${ }^{13} \mathrm{C}$ NMR: $\delta 50.3,114.8,116.2,119.7,121.4,121.8,123.2$, 127.9, 128.1, 128.3, 130.6, 137.8, 149.4, 151.3, 154.1, 155.5, 175.7. ES-MS m/z: $321[\mathrm{M}+\mathrm{H}]^{+}$. Anal. $\left(\mathrm{C}_{17} \mathrm{H}_{11} \mathrm{~N}_{3} \mathrm{O}_{4}\right): \mathrm{C}, \mathrm{H}, \mathrm{N}$.

4.3.2. 3-(1H-imidazol-1-yl)methyl-6-fluoro-9H-xanthen-9-one (1b). Starting from 2b [24] (0.19 g, $0.8 \mathrm{mmol}), 0.17 \mathrm{~g}$ of crude bromomethyl derivative were obtained, that were reacted with imidazole $(0.15 \mathrm{~g}, 2.4 \mathrm{mmol})$ and purified by flash chromatography (eluent: ethyl acetate) to yield $\mathbf{1 b}(0.05 \mathrm{~g}$, $21 \%$ ), mp 170-180 ${ }^{\circ} \mathrm{C} .{ }^{1} \mathrm{H}$ NMR: $\delta 5.31\left(\mathrm{~s}, 2 \mathrm{H}, \mathrm{CH}_{2}\right), 6.98$ (s, 1H, arom), 7.11-7.21 (m, 5H, arom), 7.65 (s, 1H, arom), 8.33 (d, $J=7.6 \mathrm{~Hz}, 1 \mathrm{H}$, arom), 8.37 (d, $J=8.4 \mathrm{~Hz}, 1 \mathrm{H}$, arom). ${ }^{13} \mathrm{C}$ NMR: $\delta 50.2$, $104.6(\mathrm{~d}, J=25.25 \mathrm{~Hz}), 113.1(\mathrm{~d}, J=22.22 \mathrm{~Hz}), 116.0,118.7,119.4,121.4,122.7,127.7,129.4(\mathrm{~d}$, $J=10.70 \mathrm{~Hz}), 130.4,137.6,143.9,156.6,157.8,166.6(\mathrm{~d}, J=254.50 \mathrm{~Hz}), 175.6 . \mathrm{ES}-\mathrm{MS} \mathrm{m} / z: 295$ $[\mathrm{M}+\mathrm{H}]^{+}$. Anal. $\left(\mathrm{C}_{17} \mathrm{H}_{11} \mathrm{FN}_{2} \mathrm{O}_{2}\right): \mathrm{C}, \mathrm{H}, \mathrm{N}$.

4.3.3. 3-(1H-imidazol-1-yl)methyl-6-chloro-9H-xanthen-9-one (1c). Starting from 2c [24] (0.50 g, $2.0 \mathrm{mmol}), 0.40 \mathrm{~g}$ of crude bromomethyl derivative were obtained, that were reacted with imidazole $(0.37 \mathrm{~g}, 6.0 \mathrm{mmol})$ and purified by flash chromatography (eluent: ethyl acetate) to yield $\mathbf{1 c}(0.06 \mathrm{~g}$, $10 \%$ ), mp 164-166 ${ }^{\circ} \mathrm{C} .{ }^{1} \mathrm{H}$ NMR: $\delta 5.31\left(\mathrm{~s}, 2 \mathrm{H}, \mathrm{CH}_{2}\right), 6.98$ (s, 1H, arom), 7.17-7.21 (m, 3H, arom), $7.38(\mathrm{dd}, J=8.4$ and $2.0 \mathrm{~Hz}, 1 \mathrm{H}$, arom), $7.50(\mathrm{~s}, 1 \mathrm{H}$, arom), $7.64(\mathrm{~s}, 1 \mathrm{H}$, arom), $8.27(\mathrm{~d}, J=8.4 \mathrm{~Hz}$, 1H, arom), 8.32 (d, $J=8.0 \mathrm{~Hz}, 1 \mathrm{H}$, arom). ${ }^{13} \mathrm{C}$ NMR: $\delta 50.4,116.3,118.2,119.5,121.6,122.9,125.1$, 125.3, 128.0, 128.3, 130.7, 137.7, 141.3, 144.3, 156.5, 156.6, 175.7. ES-MS m/z: $310[\mathrm{M}+\mathrm{H}]^{+}$. Anal. $\left(\mathrm{C}_{17} \mathrm{H}_{11} \mathrm{ClN}_{2} \mathrm{O}_{2}\right): \mathrm{C}, \mathrm{H}, \mathrm{N}$. 
4.3.4. 3-(1H-imidazol-1-yl)methyl-6-bromo-9H-xanthen-9-one (1d). Starting from $2 \mathrm{~d}(0.19 \mathrm{~g}$, $0.66 \mathrm{mmol}), 0.15 \mathrm{~g}$ of crude bromomethyl derivative were obtained, that were reacted with imidazole $(0.13 \mathrm{~g}, 1.98 \mathrm{mmol})$ and purified by flash chromatography (eluent: ethyl acetate) to yield $\mathbf{1 d}(0.04 \mathrm{~g}$, 17 \%), mp 168-170 ${ }^{\circ} \mathrm{C} .{ }^{1} \mathrm{H}$ NMR: $\delta 5.30$ (s, 2H, $\mathrm{CH}_{2}$ ), 6.98 (s, 1H, arom), 7.17-7.20 (m, 3H, arom), $7.52(\mathrm{dd}, J=8.8$ and $2.0 \mathrm{~Hz}, 1 \mathrm{H}$, arom), 7.68-7.69 (m, $2 \mathrm{H}$, arom), $8.18(\mathrm{~d}, J=8.8 \mathrm{~Hz}, 1 \mathrm{H}$, arom), $8.32\left(\mathrm{~d}, J=8.4 \mathrm{~Hz}, 1 \mathrm{H}\right.$, arom). ${ }^{13} \mathrm{C}$ NMR: $\delta 50.2,116.1,119.5,120.7,121.1,121.4,122.7,127.7$, 127.9, 128.1, 129.5, 130.5, 137.6, 144.2, 156.1, 156.3, 175.9. ES-MS m/z: 353 [M - H]. Anal. $\left(\mathrm{C}_{17} \mathrm{H}_{11} \mathrm{BrN}_{2} \mathrm{O}_{2}\right): \mathrm{C}, \mathrm{H}, \mathrm{N}$.

4.3.5. 3-(1H-imidazol-1-yl)methyl-6-methoxy-9H-xanthen-9-one (1e). Starting from 2e [25] (0.42 $\mathrm{g}, 1.75 \mathrm{mmol}), 0.57 \mathrm{~g}$ of crude bromomethyl derivative were obtained, that were reacted with imidazole (0.36 g, $5.25 \mathrm{mmol})$ and purified by flash chromatography (eluent: petroleum ether/ethyl acetate 1:4) to yield 1e (0.07 g, $13 \%)$, mp 138-140 ${ }^{\circ} \mathrm{C}$ (ligroin). ${ }^{1} \mathrm{H}$ NMR: $\delta 3.94\left(\mathrm{~s}, 3 \mathrm{H}, \mathrm{OCH}_{3}\right), 5.29$ (s, 2H, $\left.\mathrm{CH}_{2}\right), 6.87$ (d, J = 2.4 Hz, 1H, arom), 6.96-6.98 (m, 2H, arom), 7.13 (s, 1H, arom), 7.16-7.18 (m, 2H, arom), $7.63\left(\mathrm{~s}, 1 \mathrm{H}\right.$, arom), $8.25\left(\mathrm{~d}, J=8.8 \mathrm{~Hz}, 1 \mathrm{H}\right.$, arom), $8.32\left(\mathrm{~d}, J=8.0 \mathrm{~Hz}, 1 \mathrm{H}\right.$, arom).${ }^{13} \mathrm{C}$ NMR: $\delta 50.2,55.9,100.2,113.5,115.7,115.8,119.4,121.6,122.3,127.6,128.3,130.3,137.6,143.2$, 156.5, 158.0, 165.2, 175.7. ES-MS m/z: $307[\mathrm{M}+\mathrm{H}]^{+} .329[\mathrm{M}+\mathrm{Na}]$. Anal. $\left(\mathrm{C}_{18} \mathrm{H}_{14} \mathrm{~N}_{2} \mathrm{O}_{3}\right): \mathrm{C}, \mathrm{H}, \mathrm{N}$.

4.3.6. 3-(1H-imidazol-1-yl)methyl-6-isopropoxy-9H-xanthen-9-one (1f). Starting from 2f [24] $(0.13 \mathrm{~g}, 0.48 \mathrm{mmol}), 0.10 \mathrm{~g}$ of crude bromomethyl derivative were obtained, that were reacted with imidazole $(0.09 \mathrm{~g}, \quad 1.44 \mathrm{mmol})$ and purified by flash chromatography (eluent: dichloromethane/methanol 9.5:0.5) to yield $\mathbf{1 f}(0.02 \mathrm{~g}, 3 \%)$, mp 119-121 ${ }^{\circ} \mathrm{C} .{ }^{1} \mathrm{H}$ NMR: $\delta 1.42(\mathrm{~d}, J$ $\left.=6.0 \mathrm{~Hz}, 6 \mathrm{H}, 2 \times \mathrm{CH}_{3}\right), 4.67-4.70(\mathrm{~m}, 1 \mathrm{H}, \mathrm{CH}), 5.28\left(\mathrm{~s}, 2 \mathrm{H}, \mathrm{CH}_{2}\right), 6.82(\mathrm{~d}, J=2.0 \mathrm{~Hz}, 1 \mathrm{H}$, arom $)$, $6.91(\mathrm{dd}, J=9.2$ and $2.0 \mathrm{~Hz}, 1 \mathrm{H}$, arom), 6.98 (s, 1H, arom), 7.09 (s, 1H, arom), 7.14-7.16 (m, 2H, arom), 7.66 (s, 1H, arom), $8.21\left(\mathrm{~d}, J=8.8 \mathrm{~Hz}, 1 \mathrm{H}\right.$, arom), $8.29\left(\mathrm{~d}, J=8.0 \mathrm{~Hz}, 1 \mathrm{H}\right.$, arom). ${ }^{13} \mathrm{C}$ NMR: $\delta 21.8$ (2C), 50.3, 70.8, 101.6, 114.4, 115.4, 115.8, 119.3, 121.7, 122.2, 127.6, 128.3, 130.5, 137.6, 143.1, 156.5, 156.0, 163.7, 175.6. ES-MS m/z: $335[\mathrm{M}+\mathrm{H}]^{+}$. Anal. $\left(\mathrm{C}_{20} \mathrm{H}_{18} \mathrm{~N}_{2} \mathrm{O}_{3}\right): \mathrm{C}, \mathrm{H}, \mathrm{N}$. 
4.3.7. 3-(1H-imidazol-1-yl)methyl-6-cyclopentyloxy-9H-xanthen-9-one (1g). Starting from $2 \mathrm{~g}$ [24] (0.23 g, $0.78 \mathrm{mmol}), 0.27 \mathrm{~g}$ of crude bromomethyl derivative were obtained, that were reacted with imidazole $(0.16 \mathrm{~g}, 2.34 \mathrm{mmol})$ and purified by flash chromatography (eluent: ethyl acetate) to yield 1 g (0.01 g, 4 \%), mp 108-110 ${ }^{\circ} \mathrm{C} .{ }^{1} \mathrm{H}$ NMR: $\delta$ 1.69-1.70 (m, 2H, $\left.\mathrm{CH}_{2}\right), 1.82-2.01(\mathrm{~m}, 6 \mathrm{H}, 3 \mathrm{x}$ $\left.\mathrm{CH}_{2}\right), 4.87-4.88(\mathrm{~m}, 1 \mathrm{H}, \mathrm{CH}), 5.29\left(\mathrm{~s}, 2 \mathrm{H}, \mathrm{CH}_{2}\right), 6.83(\mathrm{~d}, J=2.4 \mathrm{~Hz}, 1 \mathrm{H}$, arom), $6.92(\mathrm{dd}, J=8.8$ and $2.4 \mathrm{~Hz}, 1 \mathrm{H}, \operatorname{arom}), 6.98(\mathrm{~s}, 1 \mathrm{H}, \operatorname{arom}), 7.11(\mathrm{~s}, 1 \mathrm{H}, \operatorname{arom}), 7.16-7.18(\mathrm{~m}, 2 \mathrm{H}$, arom), $7.63(\mathrm{~s}, 1 \mathrm{H}$, arom), 8.22 (d, $J=9.2 \mathrm{~Hz}, 1 \mathrm{H}$, arom), 8.32 (d, $J=8.0 \mathrm{~Hz}, 1 \mathrm{H}$, arom). ${ }^{13} \mathrm{C}$ NMR: $\delta 24.1(2 \mathrm{C}), 32.9$ (2C), 50.3, 80.5, 101.7, 114.7, 115.4, 115.9, 119.5, 121.8, 122.3, 127.7, 128.2, 130.4, 137.7, 143.2, 156.6, 158.0, 164.1, 175.8. ES-MS m/z: $361[\mathrm{M}+\mathrm{H}]^{+}, 383[\mathrm{M}+\mathrm{Na}]$. Anal. $\left(\mathrm{C}_{22} \mathrm{H}_{20} \mathrm{~N}_{2} \mathrm{O}_{3}\right): \mathrm{C}, \mathrm{H}, \mathrm{N}$.

4.3.8. 3-(1H-imidazol-1-yl)methyl-6-cyclopropylmethoxy-9H-xanthen-9-one (1h). Starting from $2 \mathbf{h}(0.08 \mathrm{~g}, 0.30 \mathrm{mmol}), 0.08 \mathrm{~g}$ of crude bromomethyl derivative were obtained, that were reacted with imidazole $(0.06 \mathrm{~g}, 0.90 \mathrm{mmol})$ and purified by flash chromatography (eluent: ethyl acetate) to yield $1 \mathbf{h}(0.06 \mathrm{~g}, 60 \%)$, mp $135-136{ }^{\circ} \mathrm{C}$ (ligroin). ${ }^{1} \mathrm{H}$ NMR: $\delta$ 0.41-0.42 (m, 2H, CH 2$), 0.71-0.72(\mathrm{~m}$, $\left.2 \mathrm{H}, \mathrm{CH}_{2}\right), 1.34-1.36(\mathrm{~m}, 1 \mathrm{H}, \mathrm{CH}), 3.94\left(\mathrm{~d}, J=6.8 \mathrm{~Hz}, 2 \mathrm{H}, \mathrm{CH}_{2} \mathrm{O}\right), 5.29\left(\mathrm{~s}, 2 \mathrm{H}, \mathrm{CH}_{2}\right), 6.84(\mathrm{~d}, J=2.0$ $\mathrm{Hz}, 1 \mathrm{H}, \operatorname{arom}), 6.96-6.99$ (m, 2H, arom), 7.12 (s, 1H, arom), 7.16-7.18 (m, 2H, arom), 7.63 (s, 1H, arom), $8.24\left(\mathrm{~d}, J=8.4 \mathrm{~Hz}, 1 \mathrm{H}\right.$, arom), $8.32\left(\mathrm{~d}, J=7.6 \mathrm{~Hz}, 1 \mathrm{H}\right.$, arom). ${ }^{13} \mathrm{C}$ NMR: $\delta 3.3(2 \mathrm{C}), 10.0$, $50.9,73.5,100.8,113.9,115.6,116.3,119.5,121.9,122.5,127.8,128.3,130.2,137.5,142.1,156.5$, 158.0, 164.7, 175.6. ES-MS m/z: $347[\mathrm{M}+\mathrm{H}]^{+}, 369[\mathrm{M}+\mathrm{Na}]$. Anal. $\left(\mathrm{C}_{21} \mathrm{H}_{18} \mathrm{~N}_{2} \mathrm{O}_{3}\right): \mathrm{C}, \mathrm{H}, \mathrm{N}$.

4.3.9. 3-(1H-imidazol-1-yl)methyl-6-phenoxy-9H-xanthen-9-one (1i). Starting from $2 \mathrm{i}(0.22 \mathrm{~g}$, $0.73 \mathrm{mmol}), 0.25 \mathrm{~g}$ of crude bromomethyl derivative were obtained, that were reacted with imidazole $(0.15 \mathrm{~g}, 2.19 \mathrm{mmol})$ and purified by flash chromatography (eluent: petroleum ether/ethyl acetate 9.5:0.5 - ethyl acetate) to yield $\mathbf{1 i}(0.03 \mathrm{~g}, 12 \%)$, mp 158-159 ${ }^{\circ} \mathrm{C} .{ }^{1} \mathrm{H}$ NMR: $\delta 5.28\left(\mathrm{~s}, 2 \mathrm{H}, \mathrm{CH}_{2}\right), 6.88$ (d, $J=1.6 \mathrm{~Hz}, 1 \mathrm{H}$, arom), $6.96(\mathrm{~s}, 1 \mathrm{H}, \operatorname{arom}), 7.04(\mathrm{~d}, J=8.4 \mathrm{~Hz}, 1 \mathrm{H}$, arom), $7.10(\mathrm{~s}, 1 \mathrm{H}$, arom $)$, 7.13-7.17 (m, 4H, arom), 7.30 (s, 1H, arom), 7.44-7.47 (m, 2H, arom), 7.65 (s, 1H, arom), 8.29 (d, J $=8.4 \mathrm{~Hz}, 1 \mathrm{H}$, arom $), 8.32\left(\mathrm{~d}, J=8.0 \mathrm{~Hz}, 1 \mathrm{H}\right.$, arom). ${ }^{13} \mathrm{C}$ NMR: $\delta 50.2,104.5,114.8,115.9,117.0$, 
$119.4,120.7$ (2C), 121.6, 122.4, 125.4, 127.6, 128.7, 130.3 (2), 130.4, 137.6, 143.5, 154.7, 156.5, 157.6, 163.9, 175.7. ES-MS m/z: $369[\mathrm{M}+\mathrm{H}]^{+}, 391[\mathrm{M}+\mathrm{Na}]$. Anal. $\left(\mathrm{C}_{23} \mathrm{H}_{16} \mathrm{~N}_{2} \mathrm{O}_{3}\right): \mathrm{C}, \mathrm{H}, \mathrm{N}$.

\subsection{Biological assays}

Inhibition of CYP11B1 and CYP11B2: V79 MZh cells expressing human CYP11B1 or CYP11B2 were grown on six-well cell culture plates with $9.6 \mathrm{~cm}^{2}$ culture area per well until confluence. The reaction was subsequently started by the addition of $\left[1,2-{ }^{3} \mathrm{H}\right]-11-$ deoxycorticosterone as substrate and corresponding inhibitor at different concentrations. After incubations of $6 \mathrm{~h}$ for V79MZh11B1 and 30 min for V79MZh11B2 cells, respectively, enzyme reactions were stopped by extracting the supernatant with chloroform. Samples were centrifuged $(10000 \times \mathrm{g}, 10 \mathrm{~min})$ and the solvent was pipetted into fresh cups. The solvent was evaporated, the steroids were re-dissolved in chloroform and analysed by HPTLC [27,28].

\subsection{Docking studies}

The CYP11B1 homology model [19] and CYP11B2 crystal (PDB ID: 4DVQ) [20] were prepared by adding hydrogens and partial charges with the Protonate3D application in MOE. Ligands were built and energy-minimized in the MMFF94s force field with MOE as well. After both parties were imported into GOLD, the heme iron was set to be the origin of active-site with a radius $19 \AA$ with automatic active-site detection switching on. 50 independent genetic algorithm iterations were performed for each run and the resulting binding poses were ranked using the goldscore function with p450_pdb parameters according to fitness scores. The most favored poses were subsequently analyzed and illustrated with the LigX module in MOE.

\section{Supplementary data}


Representative NMR spectra (compound 1e); elemental analyses of new compounds.

\section{References}

[1] P. A. Zunszain, C. Anacker, A. Cattaneo, L. A. Carvalho, C. M. Pariante, Glucocorticoids, cytokines and brain abnormalities in depression, Prog. Neuropsychopharmacol. Biol. Psychiatry 35 (3), (2011) 722-729.

[2] C. V. Montfrans, M. Stok, M. Geerkens, Biology of chronic wounds and new treatment strategies, Phlebology 29 (1 suppl) (2014) 165-167.

[3] L. Ma, L. Yin, Q. Hu, Therapeutic compounds for Cushing's syndrome: a patent review (20122016), Expert Opin. Ther. Pat. 26 (11) (2016) 1307-1323.

[4] C. G. Brilla, Renin-angiotensin-aldosterone system and myocardial fibrosis, Cardiovasc. Res. 47 (1) (2000) 1-3.

[5] S. Lucas, R. Heim, M. Negri, I. Antes, C. Ries, K. E. Schewe, A. Bisi, S. Gobbi, R. W. Hartmann, Novel Aldosterone Synthase Inhibitors with Extended Carbocyclic Skeleton by a Combined LigandBased and Structure-Based Drug Design Approach, J. Med. Chem. 51 (19) (2008) 6138-6149.

[6] J. P. Papillon, C. Lou, A. K. Singh, C. M. Adams, G. M. Ksander, M. E. Beil, W. Chen, J. LeungChu, F. Fu, L. Gan, C. W. Hu, A. Y. Jeng, D. LaSala, G. Liang, D. F. Rigel, K. S. Russell, J. A. Vest, C. Watson, Discovery of N-[5-(6-Chloro-3-cyano-1-methyl-1H-indol-2-yl)-pyridin-3-ylmethyl]ethanesulfonamide, a Cortisol-Sparing CYP11B2 Inhibitor that Lowers Aldosterone in Human Subjects, J. Med. Chem. 58 (2015) 9382-9394.

[7] S. B. Hoyt, W. Petrilli, C. London, G. B. Liang, J. Tata, Q. Hu, L. Yin, C. J. van Koppen, R. W. Hartmann, M. Struthers, T. Wisniewski, N. Ren, C. Bopp, A. Sok, T. Q. Cai, S. Stribling, L. Y. Pai, X. Ma, J. Metzger, A. Verras, D. McMasters, Q. Chen, E. Tung, W. Tang, G. Salituro, N. Buist, J. 
Clemas, G. Zhou, J. Gibson, C. A. Maxwell, M. Lassman, T. McLaughlin, J. Castro-Perez, D. Szeto, G. Forrest, R. Hajdu, M. Rosenbach, Y. Xiong, Discovery of Benzimidazole CYP11B2 Inhibitors with in Vivo Activity in Rhesus Monkeys, ACS Med. Chem. Lett. 6 (2015) 573-578.

[8] W. L. Petrilli, S. B. Hoyt, C. London, D. McMasters, A. Verras, M. Struthers, D. Cully, T. Wisniewski, N. Ren, C. Bopp, A. Sok, Q. Chen, Y. Li, E. Tung, W. Tang, G. Salituro, I. Knemeyer, B. Karanam, J. Clemas, G. Zhou, J. Gibson, C. A. Shipley, D. J. MacNeil, R. Duffy, J. R. Tata, F. Ujjainwalla, A. Ali, Y.Xiong, Discovery of Spirocyclic Aldosterone Synthase Inhibitors as Potential Treatments for Resistant Hypertension, ACS Med. Chem. Lett. 8 (2017) 128-132.

[9] W. Zhu, Q. Hu, N. Hanke, C. J. van Koppen, R. W. Hartmann, Potent 11ß-Hydroxylase Inhibitors with Inverse Metabolic Stability in Human Plasma and Hepatic S9 Fractions To Promote Wound Healing, J. Med. Chem. 57 (18) (2014) 7811-7817.

[10] J. Emmerich, Q. Hu, N. Hanke, R. W. Hartmann, Cushing's Syndrome: Development of Highly Potent and Selective CYP11B1 Inhibitors of the (Pyridylmethyl)pyridine Type, J. Med. Chem. 56 (15) (2013) 6022-6032.

[11] A. Stefanachi, N. Hanke, L. Pisani, F. Leonetti, O. Nicolotti, M. Catto, S. Cellamare, R. W. Hartmann, A. Carotti, Discovery of new 7-substituted-4-imidazolylmethyl coumarins and 4'substituted-2-imidazolyl acetophenones open analogues as potent and selective inhibitors of steroid11ß-hydroxylase, Eur. J. Med. Chem. 89 (2015) 106-114.

[12] W. Zhu, Z. Chen, Q. Li, G. Tan, G. Hu, Inhibitors of 11ß-Hydroxylase (CYP11B1) for Treating Diseases Related to Excess Cortisol, Curr. Med. Chem. 23 (2016) 623-633.

[13] L. Yin, S. Lucas, F. Maurer, U. Kazmaier, Q. Hu, R. W. Hartmann, Novel Imidazol-1-ylmethyl Substituted 1,2,5,6-Tetrahydropyrrolo[3,2,1-ij]quinolin-4-ones as Potent and Selective CYP11B1 Inhibitors for the Treatment of Cushing's Syndrome, J. Med. Chem. 55 (2012) 6629-6633. 
[14] J. Emmerich, C. J. van Koppen, J. L. Burkhart, Q. Hu, L. Siebenbürger, C. Boerger, C. Scheuer, M. W. Laschke, M. D. Menger, R. W. Hartmann, Lead Optimization Generates CYP11B1 Inhibitors of Pyridylmethyl Isoxazole Type with Improved Pharmacological Profile for the Treatment of Cushing's Disease, J. Med. Chem. DOI: 10.1021/acs.jmedchem.7b00437 Publication Date (Web): June 1, 2017.

[15] S. Gobbi, Q. Hu, M. Negri, C. Zimmer, F. Belluti, A. Rampa, R. W. Hartmann, A. Bisi, Modulation of Cytochromes P450 with Xanthone-Based Molecules: From Aromatase to Aldosterone Synthase and Steroid 11ß-Hydroxylase Inhibition, J. Med. Chem. 56 (4) (2013) 1723-1729.

[16] S. Gobbi, Q. Hu, C. Zimmer, F. Belluti, A. Rampa, R. W. Hartmann, A. Bisi, Targeting Steroidogenic Cytochromes P450 (CYPs) with 6-Substituted 1-Imidazolylmethylxanthones, ChemMedChem 11 (16) (2016) 1770-1777.

[17] M. Recanatini, A. Bisi, A. Cavalli, F. Belluti, S. Gobbi, A. Rampa, P. Valenti, M. Palzer, A. Palusczak, R. W. Hartmann, A New Class of Nonsteroidal Aromatase Inhibitors: Design and Synthesis of Chromone and Xanthone Derivatives and Inhibition of the P450 Enzymes Aromatase and 17 $\alpha$-Hydroxylase/C17,20-Lyase, J. Med. Chem. 44 (5) (2001) 672-680.

[18] U. E. Hille, Q. Hu, M. A. E. P.-B. Mendieta, M. Bartels, C. A. Vock, T. Lauterbach, R. W. Hartmann, Steroidogenic cytochrome P450 (CYP) enzymes as drug targets: Combining substructures of known CYP inhibitors leads to compounds with different inhibitory profile, Comptes Rendus Chimie 12 (10-11) (2009) 1117-1126.

[19] Q. Hu, J. Kunde, N. Hanke, R. W. Hartmann, Identification of 4-(4-nitro-2phenethoxyphenyl)pyridine as a promising new lead for discovering inhibitors of both human and rat 11ß-Hydroxylase, Eur. J. Med. Chem. 96 (2015) 139-150. 
[20] N. Strushkevich, A. A. Gilep, L. Shen, C. H. Arrowsmith, A. M. Edwards, S. A. Usanov, H. W. Park, Structural Insights into Aldosterone Synthase Substrate Specificity and Targeted Inhibition, Mol. Endocrinol. 27 (2) (2013) 315-324.

[21] L. Yin, Q. Hu, R. W. Hartmann, 3-Pyridyl Substituted Aliphatic Cycles as CYP11B2 Inhibitors: Aromaticity Abolishment of the Core Significantly Increased Selectivity over CYP1A2, PLoS One 7 (11) (2012) e48048.

[22] Q. Hu, L. Yin, A. Ali, A. J. Cooke, J. Bennett, P. Ratcliffe, M. M. Lo, E. Metzger, S. Hoyt, R. W. Hartmann, Novel Pyridyl Substituted 4,5-Dihydro-[1,2,4]triazolo[4,3-a]quinolines as Potent and Selective Aldosterone Synthase Inhibitors with Improved in Vitro Metabolic Stability, J. Med. Chem. 58 (5) (2015) 2530-2537.

[23] S. Gobbi, C. Zimmer, F. Belluti, A. Rampa, R. W. Hartmann, M. Recanatini, A. Bisi, Novel Highly Potent and Selective Nonsteroidal Aromatase Inhibitors: Synthesis, Biological Evaluation and Structure-Activity Relationships Investigation, J. Med. Chem. 53 (14) (2010) 5347-5351.

[24] P. Da Re, S. Malandrino, P. Valenti, G. Pifferi, Xanthone derivatives, their preparation and use. EP586960 A1, 1994.

[25] S. Wang, K. Xie, Z. Tan, X. An, X. Zhou, C. C. Guo, Z. Peng, One-Step Preparation of Xanthones via Pd-Catalyzed Annulation of 1,2-Dibromoarenes and Salicylaldehydes, Chem. Commun. (Camb) 42 (2009) 6469-6471.

[26] 2a: mp 202-204 ${ }^{\circ} \mathrm{C},{ }^{1} \mathrm{H}$ NMR: $\delta=2.56$ (s, 3H, $\mathrm{CH}_{3}$ ), 7.30 (s, 1H, arom), 7.37 (s, 1H, arom), 8.18 (dd, $J=8.8$ and $2.0 \mathrm{~Hz}, 1 \mathrm{H}$, arom), $8.25(\mathrm{~d}, J=8.0 \mathrm{~Hz}, 1 \mathrm{H}$, arom), $8.38(\mathrm{~d}, J=2.0 \mathrm{~Hz}, 1 \mathrm{H}$, arom), $8.52(\mathrm{~d}, J=8.8 \mathrm{~Hz}, 1 \mathrm{H}$, arom $)$.

[27] K. Denner, J. Doehmer, R. Bernhardt, Cloning of CYP11B1 and CYP11B2 from normal human adrenal and their functional expression in COS-7 and V79 chinese hamster cells, Endocr. Res. 21 (12) (1995) 443-448. 
[28] P. B. Ehmer, M. Bureik, R. Bernhardt, U. Muller, R. W. Hartmann, Development of a test system for inhibitors of human aldosterone synthase (CYP11B2): screening in fission yeast and evaluation of selectivity in V79 cells, J. Steroid. Biochem. Mol. Biol. 81 (2) (2002) 173-179. 